\title{
Locus \& Homoeros: interseção e intercessão segundo a poética não-aristotélica de Horácio Costa
}

\author{
Mauricio Matos ${ }^{1}$ \\ Universidade Federal do Rio de Janeiro
}

s poetas não têm biografia. Sua obra é sua biografia." Assim abre Octavio Paz seu célebre ensaio sobre Fernando Pessoa, para adiante afirmar: "Escrevemos para ser o que somos ou para ser aquilo que não somos. Em um ou em outro caso, nos buscamos a nós mesmos. E se temos a sorte de encontrar-nos [é] sinal de criação" (PAZ, 2006). Convencido de que essas mesmas palavras poderiam ter sido escritas sobre qualquer grande poeta de qualquer língua, lugar ou tempo, percebo nelas a criação em Horácio Costa, na invenção biográfica de um sujeito poético em Satori, a um só tempo título de seu segundo livro de poemas (São Paulo, 1989) e palavra japonesa para significar iluminação, revelação.

Paulistanas \& Homoeróticas, dois adjetivos e dois substantivos conjugados, ambos no feminino, ambos no plural: viagens por interseções físicas, regidas por Locus e Homoeros, deuses que, a reivindicar sua existência mítica, saltam significantes, criados por satori a partir do lugar entre minha própria leitura e a poesia de Horácio Costa, que ilumina e revela o leitor-cúmplice, segundo o que de si puder perceber nos versos lidos. Horácio Costa, poeta, é metonímia de todos: como São Paulo é de todos os lugares e o homoerotismo, em sua poesia, de todos os erotismos.

Segundo Álvaro de Campos, "assim como se podem formar, se formaram, e foi útil que se formassem, geometrias não-euclidianas, não vejo razão para que não possam formar-se, não se formem, e não seja útil que se formem, estéticas não-aristotélicas” (1995). Ora, em O Livro dos Fracta (São Paulo/

Doutor em Literatura Portuguesa (PUC-Rio). Pesquisador de Pós-Doutorado do CNPq na UFRJ (2006-2008). Poeta, autor de Aquém das Retinas (Rio de Janeiro, 2006). 
México, 1990), "se trata, en palabras del propio Costa, de una geometría noeuclidiana”, afirma Manuel Ulacia (2004). Logo, trata-se de uma poética nãoaristotélica, aquela para a qual, segundo o heterônimo de Pessoa, "o equilíbrio vital é, não de um fato direto [...], mas o resultado abstrato do encontro de dois fatos".

Paulistanas inicia-se nos diálogos de "Conversação com Tàpies": diálogo entre a poesia e as artes plásticas, aliás freqüente na produção poética de Horácio Costa, que já se estabelecera com Rembrandt, Cézanne e Jacques Louis David, entre outros, diálogo também estabelecido entre o poeta cosmopolita brasileiro e o pintor abstracionista catalão, em que o primeiro se outra no segundo, para na última das nove partes de que é composto o poema responder por este "que tudo o que há se anuncia / livre / belo / nobre / ágil / / - anjos esverdeados / no momento da transformação" (IX) do pictórico ao poético, como "o rio" que se transforma em "espuma" (I), pois "Tàpies ensina: com o gesto" e o poeta descreve "a incisão de mais um alfabeto / que incide sobre a superfície rugosa / da caixa de papelão desdobrada" em obra de arte (II). E pergunta o poeta a Tàpies: "o caixote rasgado / [...] / foste tu ao seu encontro / ou veio ele ao teu?”. E pergunto ao poeta: foste tu ao encontro de Tàpies, ou veio ele ao teu? "e o xingamento, quando se faz / oração?” (III). Quis não transcrever este último dístico, por deixá-lo ao próximo leitor incógnito, mas não me foi possível. Perdoe-me o poeta. Satori...

No sexto dos "Dezesseis Graus na Paulista", "o deambular permanece / quando não me encontro perto / ou dentro de ti / exilo-me e dói / - quem compreenderia? / os capazes de extrair beleza / do pó acumulado / sobre um arame farpado?" (VI). Estes, sensorialmente semelhantes ao poeta, percebem como ele a mística Paulista, dilacerada, ascendendo em graus, "sob o signo de Saulo"(IX), onde "no chiaroscuro pinta algum / Caravaggio anônimo" (X). E os "Dezesseis Graus na Paulista" revelam-se "onze tempos de passeio redivivos", que o poeta percorre "em três minutos / cubos / cubos / cubos", a afirmar sua geometria não-euclidiana, sua estética não-aristotélica, a dialogar com a Paulista de quarenta páginas adiante, onde o "observador tornado prisma" de uma "cidade suja / calcinada" descobre-se também filho da cal, sob o olhar de Locus.

Em Homoeróticas, abre-se "A Voz do Brasil" sobre um sujeito poético que, no aeroporto, ouve a enumeração literal de entrelugares, Bogotá e Manaus, es- 
calas entre São Paulo e a Cidade do México, revelando que "A realidade engana [...] / E a Voz do Brasil, masculina / Mas não viril, / Quem diria, é mesmo / De gueixa".

"A Traição de Rita [Hayworth], a Digna-de-Feno", na evocação de Manuel Puig - segundo as palavras do próprio poeta, "uma espécie de manifesto por uma cultura latino-americana que deixe de lado a sombra dos militares, do autoritarismo, e que possa encarar os absolutos da existência sem a mordaça das ordens instituídas" - parte de um inquieto deambular por museus - "Uma visita a Praga", "Ao Prado", "Ao Metropolitan" -, que procura se lembrar onde viu, não o "Jardim das Delícias", mas o "Carro de Feno" de Hieronymus Bosch, para chegar, possuído pela linguagem, por via gongórica, serpentinata... "Aonde mais, caralho?" A interjeição exata, para ser dita com a boca cheia e "novos olhos", que possam ser outros em relação aos que aprenderam a ser o que jamais deveriam ter sido. O poeta não lamenta, denuncia, pungente, e com algum humor, quase negro: "Os homossexuais", "Não temos filhos, temos 'relacionamentos' / e nossa família às vezes desaparece [...] // [...] num crime quase nunca casual, / Cometido numa praça qualquer, às vezes sob o nariz / De polícias e circunstantes, e tantas, / Com a bênção de plantão de um Cardeal / Eminentíssimo" na Espanha, no México, no Rio de Janeiro...

"Aonde mais, caralho?", haveria de gritar, agora, o poeta que "não [tem] a menor intenção de calar-[se]", em revolta contra "as burguesinhas do catolicismo", as de Cesário Verde, de agora, de sempre, "Devotas do cine e da Virgem de Luján", e dizer-lhes: "Entendei-me, não é por ver a minha própria voz impressa, é que / De fato tenho algo a dizer".

Também o lirismo, na concepção mais antiga do termo, mas de tratamento rigorosamente singular e novo, deixa sua marca na dor que o leitor-cúmplice poderá sentir - se puder, na "dor lida" sentir - nos dois belíssimos sonetos, quase sempre em decassílabos brancos: "A Aids fez suas vítimas, e eu fico. // A cada folha que caía, eu contava / menos um linfócito, e sorria. / A planta ao adubo não respondia": testemunho da Aids, o poeta - um "Arcimboldi Textual", como lhe chamara Severo Sarduy, já na década de 80 - preserva, na figueira antropomorfizada no corpo de Luís Varela Beltrán, a sua memória num epitáfio de versos, sobriamente intitulado em latim: "Ficus".

$\mathrm{Na}$ seqüência de poemas em prosa com que se fecha o volume, desperta a atenção a imprevisibilidade estética em "The Rosy Crucifixion" (poema ho- 
mônimo da célebre trilogia de Henry Miller), em cujo último parágrafo-verso a música sacra ocidental e um afro-brasileiro espírito santo, na interseção de sentidos, promovem uma imprevista intercessão: "Sobre minha cabeça persiste um discreto rufar de asas abertas. Kyrie Elêison... Kyrie... Kyrie... Seguirei imaginando que a Pomba-Gira me protege". "The Rosy Crucifixion": só um poeta latino-americano, consciente e militante, poderia tê-lo escrito, sob as bênçãos de Homoeros.

Barroco? Maneirista? Surreal? Concreto? Abstrato? Moderno ou Pós-Moderno? Imprevisível. Aristotélico ou não, seria agressivo e desnecessário aprisionar em rótulos a multiplicidade de Horácio Costa, pois, como já disse sobre ele José Saramago no prefácio que escreveu a O Menino e o Travesseiro (São Paulo/San Diego, 1994), "'ao poeta - sonho e pensamento reunidos - não se lhe há de exigir que nos venha explicar os motivos, desvendar os caminhos e assinalar os propósitos" de sua obra (SARAMAGO apud COSTA, 2004).

Melhor será celebrar sua poesia, a iniciar uma coleção de poetas brasileiros, Série Caixa Preta, Lumme Editor; e perceber, no bom gosto do box prateado, em cujo interior se encontram versos reunidos, a sua São Paulo, o seu Homoerotismo com o $H$ maiúsculo de um ibero-americano que tem "algo a dizer", e sabe disso.

\section{Referências Bibliográficas}

CAMPOS, Álvaro de. Apontamentos para uma estética não-aristotélica. In: PESSOA, Fernando. Obras em prosa. Org. Cleonice Berardinelli. $8^{a}$ reimpressão. Rio de Janeiro: Nova Aguilar, 1995.

PAZ, Octavio. O desconhecido de si mesmo - Fernando Pessoa. In: Signos em rotação. Trad. Sebastião Uchoa Leite. 3. ed. São Paulo: Perspectiva, 2006.

SARAMAGO, José. Prefácio a O Menino e o Travesseiro. In: COSTA, Horácio. Fracta Antologia Poética. Org. Haroldo de Campos. São Paulo: Perspectiva, 2004.

ULACIA, Manuel. Quadragésimo / Cuadragésimo de Horácio Costa. In: COSTA, Horácio. Fracta - Antologia Poética. Org. Haroldo de Campos. São Paulo: Perspectiva, 2004. 